\title{
鉄筋で補強した円形コンクリート充填鋼管柱の耐火性能 FIRE RESISTANCE OF CIRCULAR STEEL TUBE COLUMNS INFILLED WITH REINFORCED CONCRETE
}

\author{
一戸康生 ${ }^{*}$, 鈴木弘之**, 久保田一男*, 平山博已* \\ 上田弘樹***, 湯谷孝夫**** \\ Yasuo ICHINOHE, Hiroyuki SUZUKI, Kazuo KUBOTA, \\ Hiromi HIRA YAMA, Hiroki UEDA and Takao YUTANI
}

\begin{abstract}
This study deals with the elasto-plastic beam-column behavior of circular steel tube columns infilled with reinforced concrete subjected to fire. Based upon the stress-strain characteristics of materials at high temperatures and the mechanics of column deflection curves, a numerical analysis method has been developed to simulate the time historical response. This method can provide a fairly good estimation for the fire resistant performance of the column. It is found that, comparing a proposed simpler superposed strength theory with the above refined numerical solution, the theory gives a satisfactory approximation to predict reinforcement effects of both steel bars and hoops on the ultimate strength of such columns.
\end{abstract}

Keywords: concrete filled steel tube, beam-column、fire resistance, numerical analysis、superposed strength コンクリート充填銅管、ビームコラム、耐火性能、数值解析、累加強度

\section{1.はじめに}

酎火被覆の無いコンクリート充填鋼管柱（以下、CFT柱）は、盛 期火災に晒され鋼管強度が低下しても、充填コンクリート部分が蟿 力支持能力を变失しない限り耐火性能を維持する。耐火被覆を省略 することにより、柱仕上げ寸法の低減、仕上げ材の簡素伦及び工期 短縮が期待できることから、斎藤・上杉らの研究4を先駆とし、更 に近年のCFT構造の飛躍的な普及に呼応して耐火性能に関する研究

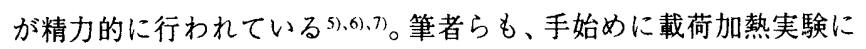
よりCFT柱の耐火性能を確認し、引続き高軸力領域への展開を目的 として充填コンクリート部分を鉄筋で補強した円形コンクリート充 填鋼管柱（以下、RCFT 柱）に関する研究を進めてきた1),21,31。

しかしながら、これら既往研究の殆どは実験の結果報告を主体と するものであり、CFT柱の熱弾塑性挙動を理論的、解析的に扱った 研究、とりわけ、実際の火災時挙動を模擬した複合載荷加熱を受け るビームコラムを研究対象として据えているものは極めて少なく、 崩壤メカニズムに関する明快な解釈も未だ得られていない。斯かる 状況のもとでは、限られた実験結果から種々の条件下に於けるビー ムコラムの性状を予測することは困難を極める。従って、耐火性能 を設計体系として一般化・定式化するに際しては、文献8)の如く実 験資料の充分な蓄積を俟って、その評価を統計的・経験的アプロー チのみに立脚した判断規範に委ねざるを得ない。

本研究では、高温下での素材試験情報に基づいて複合載荷加熱を
受けるRCFT柱及びCFT柱の時刻歴火災応答を高精度で子測可能な 解析手法を提案し、更に、これらビームコラムの終局状態、即ち崩 壊メカニズムを明らかにした上で、RCFT柱に於ける鉄筋補強効果 の簡便な定量評価手法を導く。

\section{2. 解析対象}

ここで解析対象として扱うのは、文献1)及び2)に揭載されている 何れも外径 $D か ゙ 318.5 \mathrm{~mm}$ の円形鋼管に $\mathrm{F}_{\mathrm{c}} 60$ クラスの高強度コンク リートを充填したビームコラム試験体10体である。試験体の構成を 実験結果と併せ表 1 に示す。文献1)と2)では使用した加熱炉が異な るが、基本的には図 1 の如きセットアップで逆対称加力を与えてい る。加熱区間 $L_{o}$ は文献 1)で7.0D、文献 2)で5.5Dである。実験は次 の手順に従い実施した。即ち、1) 一定軸力 $V_{1}$ を導入する。 2 ) 柱 フェイスのモーメントが、常温時断面耐力に対して文献 1 では約 22 \%、文献 2 では約 $14 \%$ となるようなせん断力 $Q$ を与えた後、加熱を 開始する。加熱は、JIS A 1304 に規定されている標準加熱曲線に従 う。 3 ）設定した層間変形角 $R$ *に到達するまで、せん断力 $Q$ を一 定に維持する。 $R^{*}$ は、文献 1)で $0.02 \mathrm{rad}$ 、、文献 2)で $0.024 \mathrm{rad}$. であ る。4） $R$ *到達後は、崩壊に至るまで層間変形角が $R^{*}$ で一定とな るようにせん断力を制御する。この一連の載荷加熱手順の中で、上 下の載荷梁は常に平行を保持している。載荷加熱中の断面内温度分 布を熱電対で、水平変位 $\delta_{h}$ 及び軸縮み $\delta_{v}$ を変位計で測定した。ま

\footnotetext{
本論文の一部は，参考文献1)，2）及(゙3)に発表している。

* 住友金属工業建設技術部 工修

** 筑波大学機能工学系 教授・工博

$* * *$ 鴻池組本社

**** 澞池組技術研究所 工修
} 
た、実験に使用したコンクリート及び鉄筋に関しては、常温での素 材試験に加え高温下の試験を実施した。結果は次章で纏める。

\section{3. 時刻歴火炎応答解析}

本解析は高温素材試験結果を忠実にモデル化した各温度ごとの応 力 $\sigma$ 一歪 $\varepsilon$ 関係を出発点とし、各時刻の断面情報、即ち、モーメン ト $M$ 一曲率 $\phi$ 関係を中間生成させ、これを元にCDC 法を用いて部 材の全体挙動を時刻歴で追跡するものである。ここでは、温度解析 による誤差を除去する為、各時刻の断面内温度分布は計測值(1.2)をそ のまま使用している。

\section{$3.1 M-\phi$ 解析と材料構成則}

図 2 に示すように断面を鎆管、鉄筋、かぶりコンクリート及びコ アコンクリートの 4 要素に分類する。主筋は実際の配筋に対して、 主筋全断面積 ${ }_{b} A$ 及び主筋配筋径 $D$ Dを等值した等価鋼管として扱う。 コアコンクリートは、フープ外径 ${ }_{h} D$ より内側の領域を指し、その力 学的特性はフープ筋による横拘束を受けるコンファインドコンク リートと見なす。断面の対称性を考慮して半円部分を解析対象とし、 径方向に 20 等分、円周方向に 30 等分の要素分割を施した。モーメ ント $\boldsymbol{M}$ 一曲率 $\phi$ 関係は、平面保持を仮定し昇温とともに時々刻々変 化する各ファイバーの応力ー歪関係を基に、軸力一定の条件で 1 分 間隔で計算される (図 9 参照)。その際、鋼材及びコンクリートの全 歪 $\varepsilon_{\mathrm{a}}$ は文献9)に做い次式で与えられると考えた。なお、銅管の局部 座屈、主筋の座屈及びコンクリートと鋼材の付着破壊は無視した。

[鋼材]

$$
\varepsilon_{\mathrm{a}}=\varepsilon+\varepsilon_{t h}+\varepsilon_{c r}
$$

[コンクリート] $\quad \varepsilon_{\mathrm{a}}=\varepsilon+\varepsilon_{t h}+\varepsilon_{c r}+\varepsilon_{t r}$ ここに、 $\varepsilon_{\mathrm{a}}$ : 全歪、 $\varepsilon=\varepsilon_{\mathrm{e}}$ (弾性歪) $+\varepsilon_{p}$ (塑性歪)、

$\varepsilon_{t h}:$ 熱膨張歪、 $\varepsilon_{c r}:$ クリープ歪、 $\varepsilon_{t r}:$ 遷移歪

\subsection{1 鋼材の応力ー歪関係}

解析に用いた鋼材の応力 $\sigma$ 一歪 $\varepsilon$ 関係は、Ralph M. Richard の提

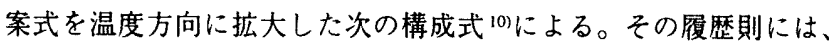
図 3 に示すような経路を描く移動硬化則を適用している。

$$
\begin{aligned}
& \sigma=\max \left\{\sigma^{(1)}, \sigma^{(2)}\right\} \\
& \sigma^{(1)}=E_{I T} \cdot \varepsilon /\left(1+\left|E_{l T} \cdot \varepsilon / \sigma_{o T}\right|^{n_{T}}\right)^{1 / n_{T}}+E_{p T^{*}} \varepsilon \\
& \sigma^{(2)}=\min \left\{E_{I T} \varepsilon, \sigma_{y T}^{\prime}\right\} \\
& こ こ に 、 E_{I T}=E_{T}-E_{p T}, E_{T}, E_{p T}, \sigma_{o r}, n_{T}, \sigma_{y T}^{\prime}: \text { それ } \\
& \text { ぞれ、T } T^{\circ} \text { に於ける初期ヤング係数、plastic modulus、 } \\
& \text { reference plastic stress、shape parameter、降伏棚を有す } \\
& \text { る場合の降伏強度 }
\end{aligned}
$$

鉄筋は高温下での素材引張試験結果を正確に再現するように、一 方、鋼管は高温引張試験を実施していないので、文献9，10）等を 参考にしながら(3)式を確定する為の 5 つの定数を表 2 の如く与え た。図 5 に見るように(3)式と引張試験結果との対応は良好である。

\section{1 .2 コンクリートの応カー歪関係}

プレーンコンクリート及びコンファインドコンクリートともに、 コンクリートの応力 $\sigma$ 一歪 $\varepsilon$ 関傒は下に示す文献 11)の提案式に従 い、履歴則は図 3 に示すモデルとした。引張強度 $\sigma$, は何れの温度下 に於いても、圧縮強度 $\sigma_{b}$ の $1 / 10$ と仮定した。

$$
\begin{gathered}
\sigma / \sigma_{b T}=3\left(\varepsilon / \varepsilon_{b T}\right) /\left(2+\left(\varepsilon / \varepsilon_{b T}\right)^{3}\right) \\
\text { ここに、 } \sigma_{b T} \text { : 圧縮強度、 } \varepsilon_{b T} \text { : 強度時歪 }
\end{gathered}
$$

文献1)及び文献2)では $\phi 50$ のシリンダーを用いた常温から $800^{\circ} \mathrm{C}$ までの高温圧縮試験を実施しており、この結果に基づき(4)式を確定 する為の 2 つの定数を表 3 の如く定めた。基準となる常温時の圧縮

\begin{tabular}{|c|c|c|c|c|c|c|c|c|c|c|c|c|c|c|c|}
\hline \multirow[b]{2}{*}{ 出典 } & \multirow[b]{2}{*}{ 試験体 } & \multirow{2}{*}{$\begin{array}{l}\text { 鎡管 } \\
\mathrm{D} \times \mathrm{t}_{\mathrm{p}}\end{array}$} & \multicolumn{2}{|c|}{ 補強鉄筋比 } & \multirow{2}{*}{$\begin{array}{c}\text { エンクリート } \\
\sigma_{\mathbf{b}} \\
\left(\mathbf{k g f} / \mathrm{cm}^{2}\right) \\
\end{array}$} & \multirow{2}{*}{$\begin{array}{c}\text { 䠽管 } \\
\sigma_{\mathrm{y}} \\
\left(\mathrm{kgf} / \mathrm{cm}^{2}\right) \\
\end{array}$} & \multirow{2}{*}{$\begin{array}{c}\text { 主筋 } \\
\sigma_{\mathrm{y}} \\
\left(\mathrm{kgf} / \mathrm{cm}^{2}\right) \\
\end{array}$} & \multirow{2}{*}{$\begin{array}{c}\text { フープ筋 } \\
\sigma_{\mathrm{y}} \\
\left(\mathrm{kgf} / \mathrm{cm}^{2}\right) \\
\end{array}$} & \multirow[b]{2}{*}{$\mathrm{L}_{\mathrm{o}}$} & \multicolumn{2}{|c|}{ 設定值 } & \multicolumn{2}{|c|}{ 実験結果 } & \multicolumn{2}{|c|}{ 解析絓果 } \\
\hline & & & $\begin{array}{c}\text { 主:筋 } \\
\mathrm{pg}_{\mathrm{g}}(\%) \\
\end{array}$ & $\begin{array}{l}\text { フープ筋 } \\
\mathrm{p}_{\mathrm{w}}(\%)\end{array}$ & & & & & & $\begin{array}{l}\mathrm{R}^{*} \\
\text { (rad.) } \\
\end{array}$ & $\begin{array}{c}\mathrm{N} \\
\text { (tonf) } \\
\end{array}$ & $\begin{array}{c}\mathrm{R}^{*} \text { 到達 } \\
(\mathrm{min}) \\
\end{array}$ & $\begin{array}{l}\text { 崩壊 } \\
(\min ) \\
\end{array}$ & $\begin{array}{c}\mathrm{R} \text { * 到達 } \\
(\mathrm{min}) \\
\end{array}$ & $\begin{array}{l}\text { 前壊 } \\
(\min ) \\
\end{array}$ \\
\hline \multirow[t]{9}{*}{ 文献 1} & BD60WD & \multirow{9}{*}{$\begin{array}{r}318.5 \\
\times 6.9\end{array}$} & 2.7 & 0.42 & 674 & 3920 & 4150 & 3930 & \multirow{9}{*}{$7.0 \mathrm{D}$} & \multirow{9}{*}{0.020} & 300 & 46 & 105 & 46 & 102 \\
\hline & BD55WD & & 2.7 & 0.42 & 671 & 3920 & 4150 & 3930 & & & 266 & 43 & 172 & 44 & 165 \\
\hline & BD50WD & & 27 & 0.42 & 652 & 4330 & 3790 & 3650 & & & 243 & 36 & 187 & 38 & 182 \\
\hline & BS45WD & & 1.4 & 0.42 & 668 & 4050 & 3850 & 3930 & & & 212 & 41 & 199 & 45 & 189 \\
\hline & BS40WD & & 1.4 & 0.42 & 652 & 4330 & 3960 & 3650 & & & 195 & 47. & 201 & 46 & 199 \\
\hline & BD50WS & & 2.7 & 0.21 & 677 & 3910 & 4150 & 3930 & & & 243 & 41 & 149 & 47 & 153 \\
\hline & $\mathrm{BDC} 50 \mathrm{WD}$ & & 2.7 & 0.42 & 681 & 3920 & 4150 & 3930 & & & 244 & 50 & 183 & - & - \\
\hline & BN35WN & & 無乙 & 無し & $66 \mathrm{~L}$ & 3920 & - & - & & & 166 & 54 & 56 & 58 & 58 \\
\hline & BN20WN & & 無L & 無L & 663 & 4050 & $=$ & - & & & 95 & 37 & 235 & 37 & 236 \\
\hline \multirow[t]{2}{*}{ 文献 2} & $\mathrm{CH} 40$ & 318.5 & 無し & 無L & 584 & 3420 & - & - & \multirow[t]{2}{*}{$5.5 \mathrm{D}$} & \multirow{2}{*}{0.024} & 164 & 47 & 47 & 56 & 56 \\
\hline & $\mathrm{CH} 35$ & $\times 10.3$ & 無人 & 舆L & 556 & 3420 & $=$ & $=$ & & & 136 & 79 & 159 & 75 & 157 \\
\hline
\end{tabular}
強度 $\sigma_{\mathrm{bRT}}$ は表 1 の $\sigma_{h}$ 值を、強度時歪 $\varepsilon_{b R T}$ は文献 1)のコンクリート に対して $0.27 \%$ 、文献 2)に対して $0.32 \%$ の値を用いた。これらは何

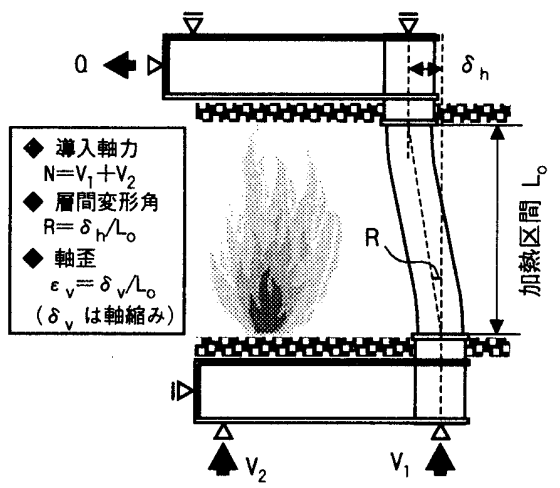

図 1 載荷条件

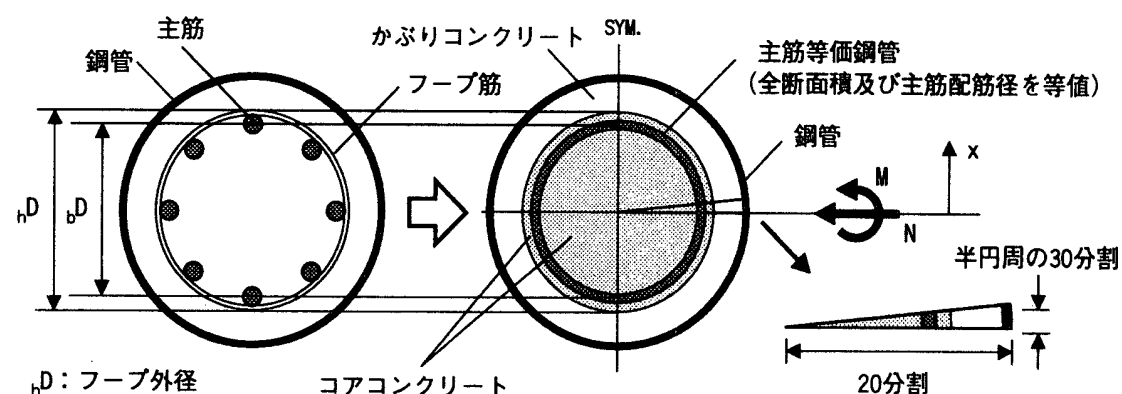

(コンファインドコンクリート)

図 2 断面の解析モデル

表 1 試験体の構成と実験結果

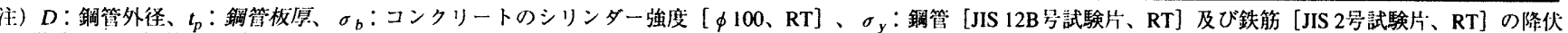

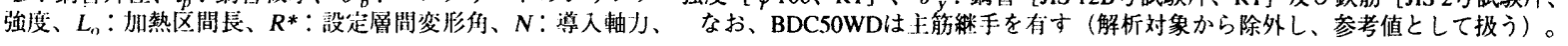


れも申100シリンダーの圧縮試験結果である。

さて、一般に横拘束を受け三軸圧縮状態にあるコンファインドコ ンクリートの圧縮強度 ${ }_{c n f} \sigma_{b}$ とプレーンコンクリートの強度 ${ }_{p} \sigma_{b}$ との 関係は、(5)式で評価し得る ${ }^{12}$ 。筆者らはフープ筋（鋼製リング）で 外周を拘束された $\phi 150$ コンクリートシリンダー41体の短柱実験を 実施し引、常温から500 $\mathrm{C}$ までの範囲内で高温下に於けるコンファイ ンドコンクリートの特性を調べた。(6)式により当該温度下でのフー
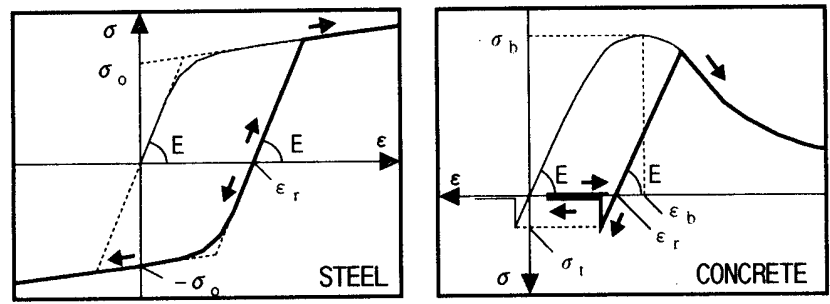

図 3 鋼材及びコンクリートの履歴モデル

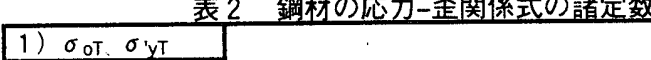

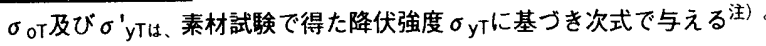

a) ラウンドハウス型の場合： $\sigma_{\mathrm{o}} \mathrm{T}=\sigma_{\mathrm{yT}} 、 \sigma^{\prime}{ }_{\mathrm{y} T}=0$

b) 降伏棚を有する場合 $\quad: \sigma_{\mathrm{o} T} / \sigma_{\mathrm{yT}}=(0.9+\mathrm{T} / 2000) 、 \sigma^{\prime}{ }_{\mathrm{yT}}=\sigma_{\mathrm{yT}}$ ここで、降伏強度 $\sigma_{\mathrm{y}} \mathrm{T}$ は、下式の通り（図 4 参照）。

[鉄筋]

$\sigma_{\mathrm{yT}} / \sigma_{\mathrm{YRT}}=\left(0^{\circ} \mathrm{C}, 1.0\right) 、\left(200^{\circ} \mathrm{C}, 1.0\right) 、\left(500^{\circ} \mathrm{C}, 0.75\right)$, 及び $\left(800^{\circ} \mathrm{C}, 0\right)$ を結ぶ線分

[鋼管]


2) $\left.E_{T}\right]$ [鉄筋と鋼管共通]

$T \leqq 600^{\circ} \mathrm{C}: E_{T} / E_{R T}=\left(1-1.05 \cdot 10^{-6} \cdot T^{2}\right) \quad($ 文献 10$\left.)\right)$

$600^{\circ} \mathrm{C}<\mathrm{T}: \quad \mathrm{E}_{\mathrm{T}} / \mathrm{E}_{\mathrm{RT}}=\left(600^{\circ} \mathrm{C}, 0.622\right)$ と $\left(800^{\circ} \mathrm{C}, 0\right)$ を結分線分

3) EPT

[鉄筋]

$T \leqq 600^{\circ} \mathrm{C} ： \quad E_{P T} / E_{R T}=1.24 \cdot 10^{-2}+1.74 \cdot 10^{-4} \cdot T-3.17 \cdot 10^{-7} \cdot T^{2}$

$600^{\circ} \mathrm{C}<\mathrm{T}: \quad \mathrm{EPT}_{\mathrm{P}} / \mathrm{E}_{\mathrm{T}}=0.0048$

[鋼管]

温度によらず、 $\mathrm{E}_{\mathrm{PT}} / \mathrm{E}_{\mathrm{T}}=0.01$

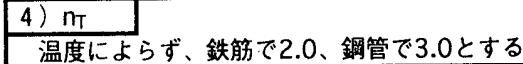

活) 鉄筋は、試呀結果に基づき $200^{\circ} \mathrm{C}$ 以下では降伏棚を有し、それを超える温度 域ではシウンドハウス型とした。鋼管は全てラウンドハウス型とした。

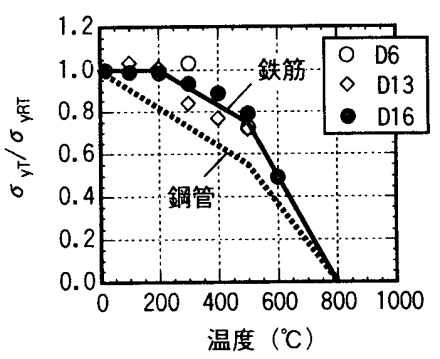

図 4 鋼材の降伏強度

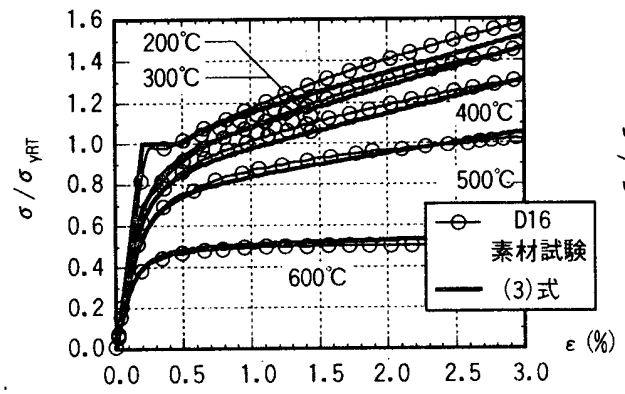

図 5 高温引張試験結果と 応力-歪関係式の対応
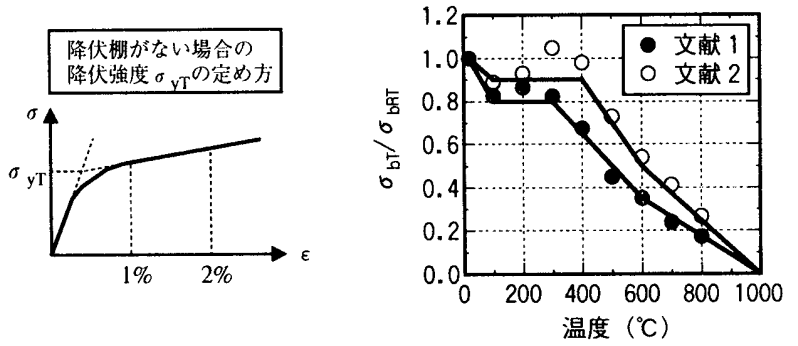

図6 コンクリートの圧縮強度と強度時歪

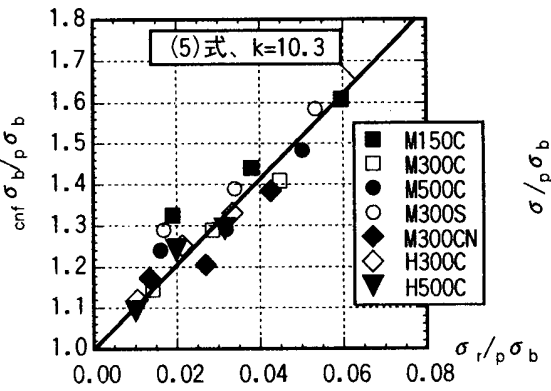

図 7 高温下におけるコンファインド コンクリートの強度特性



図 8 短柱実験結果 $\left(500^{\circ} \mathrm{C}\right)$ と 応力一歪関係式の対応 




図 $9 M-\phi\left(\varepsilon_{c}\right)$ 関係の解析プロセス
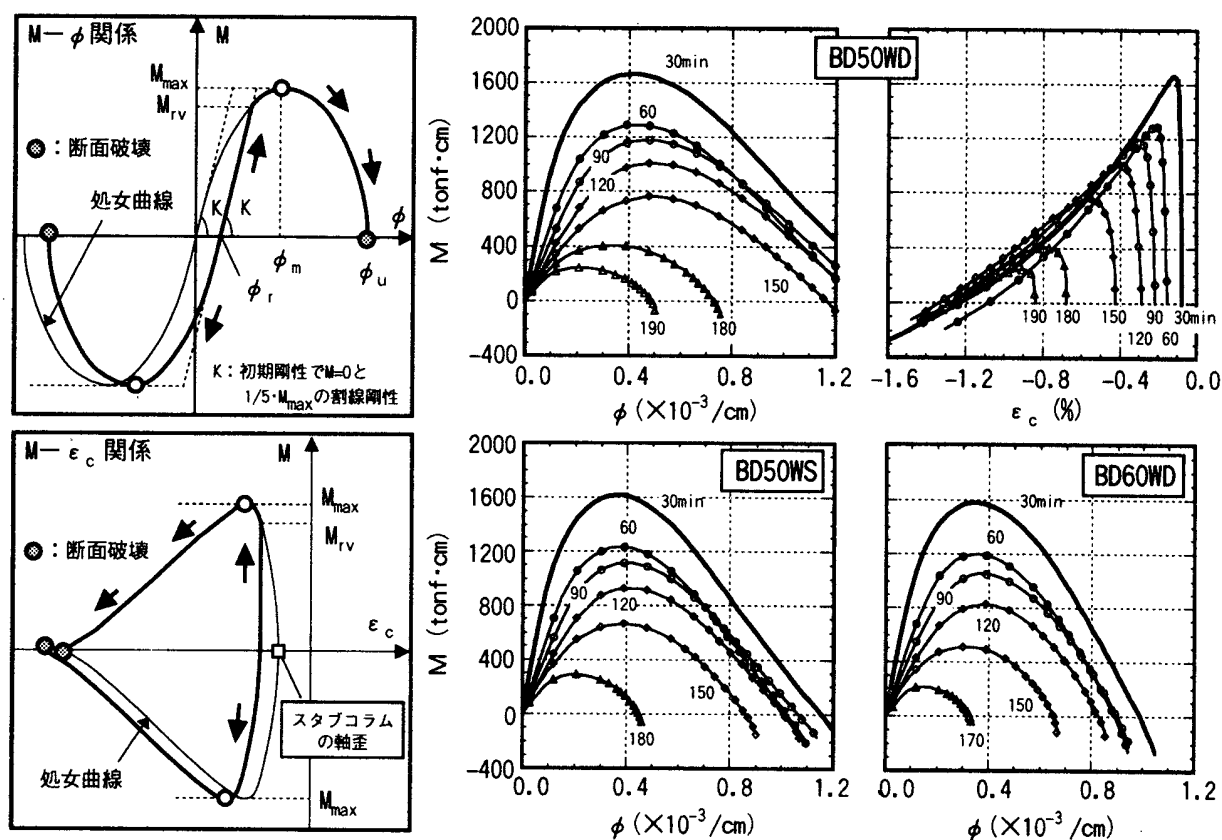

図10 モーメントM-曲率 $\phi$ 関係及びモーメントMー軸昰 $\varepsilon_{c}$ 関係
文献15）で提唱されている修正歪硬化法則に従い、クリープ歪 $\varepsilon_{c r}$ は 初期歪としてではなく塑性歪 $\varepsilon_{p}$ と連成させて扱う熱弾塑性クリープ 挙動モデルにて評価した。

[鎆材]

$\varepsilon_{c r}(\%)=10^{a / T+b} \cdot \sigma^{c / T+d} \cdot t^{c \cdot T+t}$

ここに、T: 絶対温度 $\left({ }^{\circ} \mathrm{K}\right) 、 \sigma:$ 応力 $\left(\right.$ tonf $\left./ \mathrm{cm}^{2}\right) 、 t:$ 経

過時間 $(\min ) 、 a \sim f:$ 定数で、文献 13)に従う

[コンクリート]

$\varepsilon_{c r}(\%)=10^{a T^{2}+b T+c \cdot \sigma \cdot t^{d T+e}}$

ここに、 $T$ : 温度 $\left({ }^{\circ} \mathrm{C}\right) 、 \sigma:$ 応力 $\left(\mathrm{kgf} / \mathrm{cm}^{2}\right) 、 t$ : 経過時

間 (hour)、 $a \sim e:$ 定数で、文献 14)に従う

コンクリートの遷移歪 $\varepsilon_{t r}$ は Anderberg ${ }^{16)} ら$ 指摘したもので、圧 縮載荷加熱の際に生じる熱膨張歪を抑制する方向の歪である。ここ では、文献9)に做い増分型の遷移歪評価式（(12)式）を变動圧縮応 力下で用いる。遷移歪は初期歪として扱う。

$\Delta \varepsilon_{t r}=-k_{t r} \cdot\left(\sigma / \sigma_{b R T}\right) \cdot \Delta \varepsilon_{t h}$

ここに、 $\varepsilon_{t h}:$ 熱膨張歪、 $k_{t r}$ : 比例定数で 2.35、 $\sigma$ : 圧

縮応力、 $\sigma_{b R T}$ : 常温時のコンクリートシリンダー強度

クリープ歪及び遷移歪は、各時刻に於いて曲率ゼロの状態で各 ファイバーに設定され曲率変化に伴う影響は無視している。コンク リートのクリープ歪及び遷移歪ついては、データの蓄積や実験的検 証が不十分であり、それを $\mathrm{F}_{\mathrm{c}} 60$ クラスの高強度コンクリート、更に はコンファインドコンクリートへ流用している点はいささか粗雑か つ恣意的で、今後の検討課題と認識している。しかしながら、文献 9)及び17)にも指摘されているように、これらは解析上、崩壊時刻に 与える影響は小さいものの、部材の軸縮み性状を精度良く評価する 上で非常に重要な因子である（図 12 参照）。

\subsection{4 断面の力学的性状}

ここで、上述の材料構成則及び図 9 に示す解析プロセスを経て得 られる断面の力学特性について概括しておく。図10にモーメントM 一曲率 $\phi$ 関係及びモーメント $\boldsymbol{M}$ 一図心軸歪 $\varepsilon_{\mathrm{c}}$ 関係の模式図及び解析 結果の一例を示す。モーメントは最大值 $M_{\max }$ を極めた後、コンク
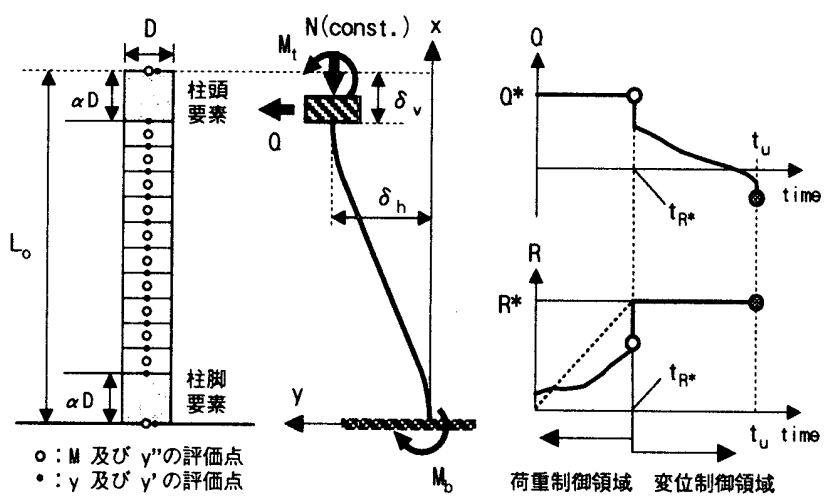

図11 解析モデルと解析条件

リート部分の応力劣化に起因する単調な耐力劣化過程に入り、限界 曲率 $\phi_{u} に$ 至って軸力支持能力を装失し曲げ圧縮破壊する。M- $\boldsymbol{中}$ 関 係の酎力劣化過程に於ける負勾配は、作用軸力が高くなる程、また 鉄筋補強量が少なくなる程、激化する。一方、軸歪は $M_{\max }$ を超過す ると、応力劣化が始まったコンクリート部分の軸酎力減少分を補い ながら、外力との釣合いを維持するために急激な増大を示す。模式 図には、次節の部材挙動解析で必要となる履歴則を併せ示している。 両履歴則の有効性は曲率の増分極性を中途で反転させた $M$ - $\phi$ 解析 を実施し、予め検証している。

\section{$3.2 \operatorname{CDC}$ 解析}

各時刻のモーメント $\boldsymbol{M}$ 一曲率 $\phi$ 関係を既知として、「系統的 CDC 数值積分法」(解析手法は、付録に詳述する)により部材挙動を時刻 歴で追跡する。解析モデルは図 11 に示すように、加熱区間 $\mathrm{L}_{\mathrm{o}}$ のみ を対象とし、それ以外の部分は剛域とした。先に見た劣化型の $M-$ $\phi$ 関係を有する部材では、柱頭・柱脚のモーメントが相等しい逆対 称型の変形モードが必ずしも現出しないので、キャンチレバーモデ ルへの簡略化は行わず素直に柱全長に亘り解析する。

柱材軸方向の要素分割は、 $M-\phi$ 劣化域に於ける材端の破壊現象 を巨視的に捉える為、柱頭・柱脚部を柱断面せい $D$ と等しい長さを 持つ要素とし、残りの部分については要素長さが大凡 $D / 2$ となるよ 

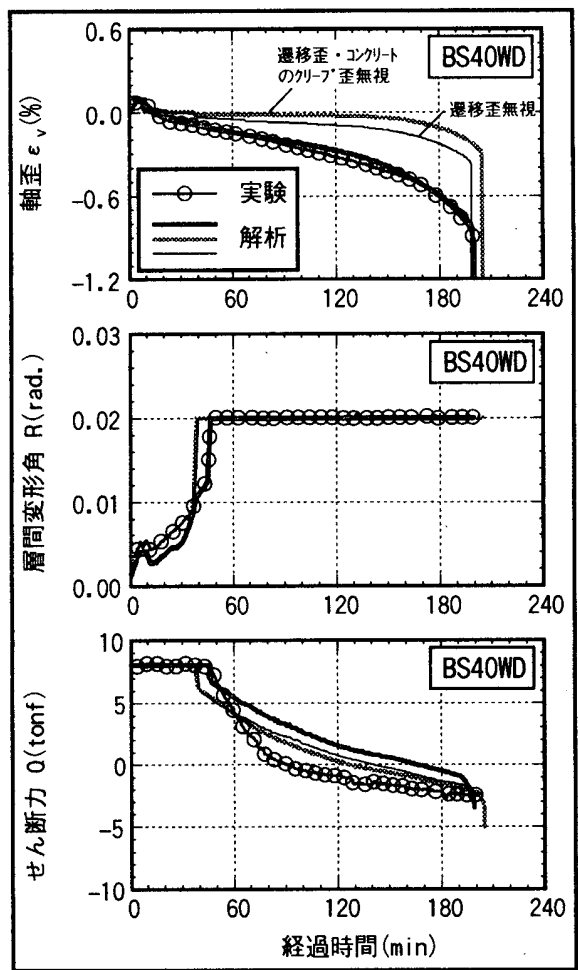

うに設定した。解析時の荷重及び変形に設定した条件は、実験時の それを再現する。即ち、時刻ゼロから $R^{*}$ 到達時まではせん断力一 定の荷重制御解析、以降は層間変形角を $R^{*}$ に固定した変位制御解 析を行う。モーメント $M$-曲率 $\phi$ 関係及びモーメント $\boldsymbol{M}$ - 図心軸 歪 $\varepsilon_{c}$ 関係の履歴モデルは図 10 に示す通りであり、かつ、温度変化 に対しては残留塑性曲率 $\phi_{\mathrm{r}}$ は変化せず、その時刻までに経験した值 が次の時刻へと引き継がれる。軸縮みす、は、CDC（柱のたわみ曲線） が確定した後、各分割要素の回転成分を考慮に入れながら $M-\varepsilon_{c}$ 関 係より算出する。解析の時間増分は 1 分とし、収束解が得られない 場合のみ時間刻みを細分化していく。なお、せん断変形は無視した。

\section{3 解析結果}

対象とする全 10 体の解析結果を図 12 に、解析值と実験值との対 応を崩壊時刻の観点から比較し図 13 に示した。図 12 にはBS40WD 試験体についてのみ、軸歪 $\varepsilon_{\mathrm{v}}$ に加えて層間变形角 $R$ と水平力 $Q$ の時 間推移を示した。実験及び解析ともに層間変形角が $R *$ 到達直前に 瞬間的に増加しているのは、柱脚・柱頭のモーメントが最大值 $M_{\max }$ に到達した為で、これは他の試験体でも共通している。解析は、何 れの試験体に於いても、軸歪 $\varepsilon_{v}$ 、層間変形角 $R$ 及び水平力 $Q$ の時間 推移を概ね良好に追跡している。 $R^{*}$ 到達時刻及び崩壊時刻に関し て、解析値と実験值との誤差は最大 10 分程度であり極めて精度の高 い予測が達成された。

$M-\phi$ 関係が負勾配を持つ部材を対象とした場合の CDC 解析の 難点は、危険断面に損傷集中が生じるため、その要素長さの取り方 により解析結果が変化することである例えは18)。試みに、柱頭・柱脚 の要素長さを $\alpha \cdot D$ と置いて、 $\alpha$ を 0.8 、或いは 1.2 とした解析を実

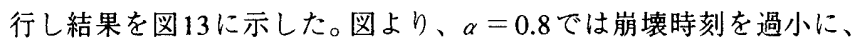
$\alpha=1.2$ では過大に評価しているのが判る。特に、相対的に軸力が 大きく早期に崩壊する試験体で、解析結果の変動が顕著である。一 方、R*到達時刻については、そもそも柱頭・柱脚モーメントの $M_{\text {max }}$

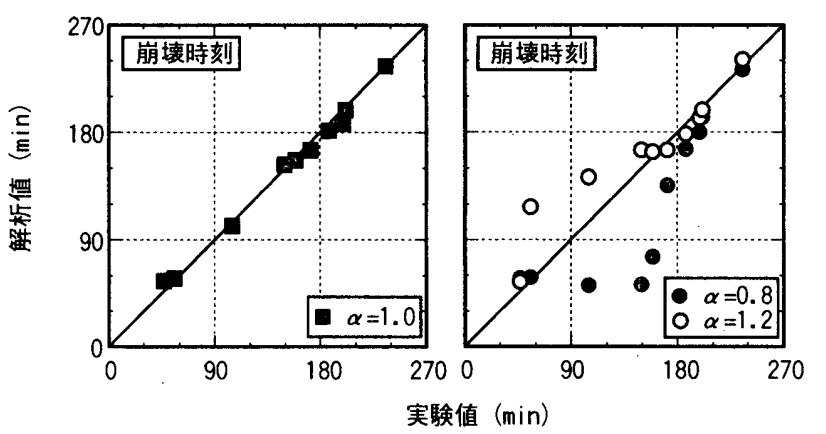

図13 解析値と実験值の対応

到達と同時刻であるから、当然のことながら要素長さを変化させて も解析結果に大きな影響を与えない。結果として、今回解析対象と した実験の範囲内では、 $\alpha=1.0 か ゙$ 実験結果を最も適切に評価する。 これは、常温のCFT 部材の弾塑性解析に於いて、この種の解析手法 をとる場合に一般的に慣用される材端要素長さに一致している。

\section{4. 考察}

以上により、本解析手法の妥当性が検証された。ここでは、主に 軸力及び鉄筋補強量を変動させたパラメトリックスタディを実施し て、文献 1 の実験結果を補いながら崩壊メカニズムとRCFT柱の鉄 筋補強効果について検討する。解析対象は以下の 5 シリーズで、断 面寸法や鉄筋の配置は文献 1 の実験と同一である。

1 ) BDWDシリーズ:RCFT 柱 $\left(p_{g}=2.7 \% 、 p_{w}=0.42 \%\right)$

2) BSWDシリーズ:RCFT 柱 $\left(p_{g}=1.4 \% 、 p_{w}=0.42 \%\right)$

$3)$ BDWS シリーズ : RCFT 柱 $\left(p_{g}=2.7 \% 、 p_{w}=0.21 \%\right)$

4) BSWS シリーズ : RCFT 柱 $\left(p_{p}=1.4 \% 、 p_{w}=0.21 \%\right)$

$5) \mathrm{BNWN}$ シリーズ:CFT 柱 [pgl主筋比、 $p_{w}$ はフープ筋比] 全シリーズに対して共通の解析条件を与える為に、先ず材料強度 を揃える。コンクリートに $\sigma_{b R T}=660 \mathrm{kgf} / \mathrm{cm}^{2}\left(\varepsilon_{b R T}=0.27 \%\right.$ 、昇温 に伴う強度低下率は文献 1 の素材試験結果に従う)、鋼管に $\sigma_{y R T}=$ 




(a) 柱頭·柱脚要素の曲率と限界曲率



(b) 柱頭・柱脚要素のモーメント・曲率の推移

図14 ビームコラムの崩壊メカニズム

$3630 \mathrm{kgf} / \mathrm{cm}^{2}$ 、鉄筋には $\sigma_{y R T}=3850 \mathrm{kgf} / \mathrm{cm}^{2}$ をちえた。これらの値は、 コンクリートに $\mathrm{F}_{\mathrm{c}} 60$ 、鋼管にSTKN490、鉄筋にSD345の使用を想 定し、それぞれの基準強度を 1.1 倍したものであり、同時に、文献 1)及び文献2)の使用素材の概ね平均的な值でもある。次に、載荷条 件を変位制御に統一する。即ち、層間変形角の時間推移は、加熱開 始時にゼロで、その後時間に正比例して増加し 1 時間で $R^{*}=$ $0.02 \mathrm{rad}$. に到達する、図 11 に破線で示した制御プログラムに従う。 4.1 ビームコラムの崩壊メカニズム

BDWD シリーズ $\left(L_{o}=6 D\right)$ の軸力比 $\left(N /{ }_{c} A \cdot \sigma_{h R T}\right) 、{ }_{c} A$ はコン クリートの断面積)が 0.5 の場合について崩壊に至る過程を図14に示 した。同図(a)及び(b)は、柱頭・柱脚要素のモーメント及び曲率に着 目し、その時刻歴を追跡したものである。併せて同図(c)にはモーメ ント分布及び曲率分布の経時変化を示した。柱頭・柱脚要素は図中 A 点で最大モーメント $M_{\text {max }}$ に対応する耐力時曲率 $\phi_{m}$ を超過し、耐 力劣化域に突入する。やがて $\mathrm{B}$ 点では設定層間変形角 $R^{*}$ に達して 水平変位が拘束され、以降 $\mathrm{C}$ 点まで弾性除荷域に留まり、曲率は暫 くほほ一定値 $\phi_{c}$ (安定曲率) に停留する。C点では、温度の上昇に 伴い断面性能が劣化し、柱頭・柱脚要素は再び処女曲線上の耐力劣 化域に復帰する。ほどなく、D 点では柱脚要素が耐力劣化域に留 まったまま、柱頭要素が弾性除荷する分岐現象が生じ、系の逆対称 モードが崩れる。劣化域の処女曲線を進路とする柱脚要素の曲率は、 やがて断面性能の劣化と相まち限界曲率 $\phi_{u}$ に接近し、 $\phi_{u}$ を突破して 解析が終了するか、さもなくば、時間増分をいくら細分しても収束 解の得られない状態に陥る。後者は、軸力一定の条件下では、もは や釣合い状態を見出せない安定限界である。

柱頭・柱脚要素のモーメント及び曲率の分岐現象は、図15に示す ようなビームコラムの耐力劣化域に於ける接線剛性が、水平弾性剛 性 $K_{l}$ の丁度半分になった時点で発生する191。従って、軸力が高いも のほど劣化域の負勾配が急激となり、分岐発生の可能性が高まる。

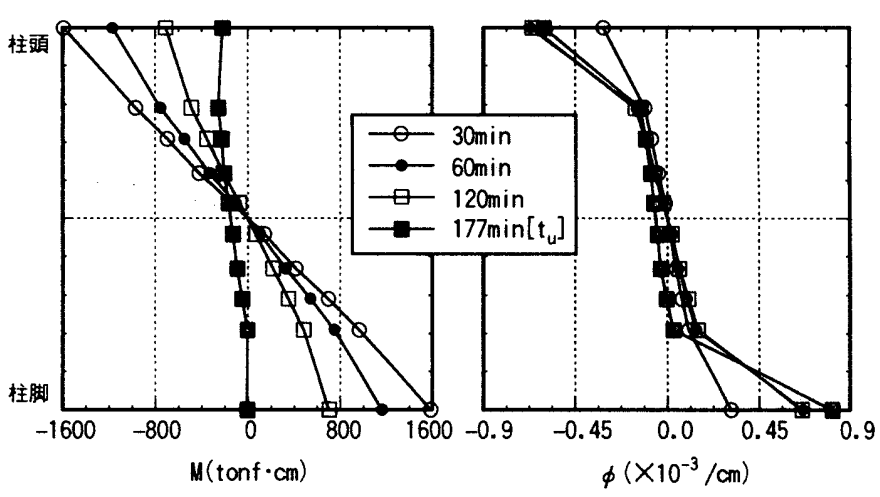

（c）モーメント分布及び曲率分布
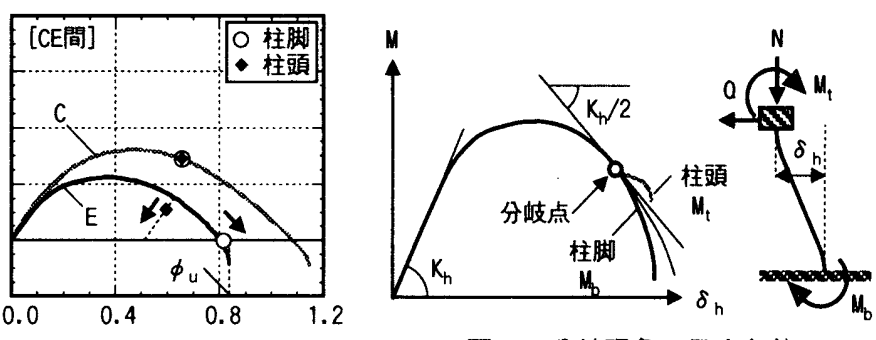

図15 分岐現象の発生条件

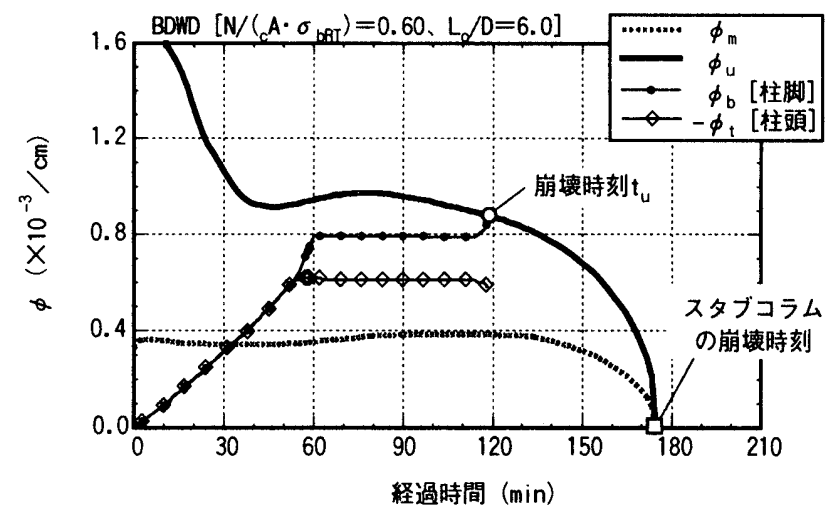

図16 柱頭·柱脚の曲率と限界曲率（高軸力の場合）

実際、図 16 に示すBDWDシリーズで軸力比 0.6 の場合には、耐力 時曲率 $\phi_{m}$ を超過し設定層間変形角 $R *$ に到達する前に早々に分岐が 発生している。結果として、柱脚要素の安定曲率 $\phi_{c}$ が $0.8 \times 10^{3} / \mathrm{cm}$ レベルで高止まりし限界曲率への到達時刻が早まるので、分岐現象 を考慮しないキャンチレバーモデルによる解析と比べて相対的に崩 壊時刻が短く評価される。更に高軸力になると、酎力時曲率 $\phi_{m}$ を突 破後に分岐した一方の要素が、そのまま限界曲率 $\phi_{u} に$ 達して崩壊す る。他方、低軸力の場合には歴然とした分岥現象が観察されず、崩 壊時刻までほほ逆対称モードを維持するものもある。何れの場合に 於いても、柱頭、柱脚、或いはその両方の要素に図 14(c)に見るよう な曲率集中が生じ、モーメント劣化を伴いながら急速に曲率が限界 値 $\phi_{u}$ に接近することで、解析上の崩壊時刻が確定する。

ここで、実際の破壊形態と解析との対応について考える。実験後、 銅管を切断しコンクリートの状況を観察した結果、全ての試験体で 材端の曲げひび割れとは別に、2.0D 3.0D 程度の広がりを有する 斜めひび割れが観察された1).21。殆どの斜めひび割れは材端フェイス から約 $0.1 \mathrm{D} \sim 0.8 \mathrm{D}$ 程度離れた位置を起点としており、常温の円形 CFTビームコラム実験で、特に高軸力の場合に於いて、危険断面近 傍に観察される曲げ破壊形態 ${ }^{200} に$ 良く似た様相を呈している。一方、 

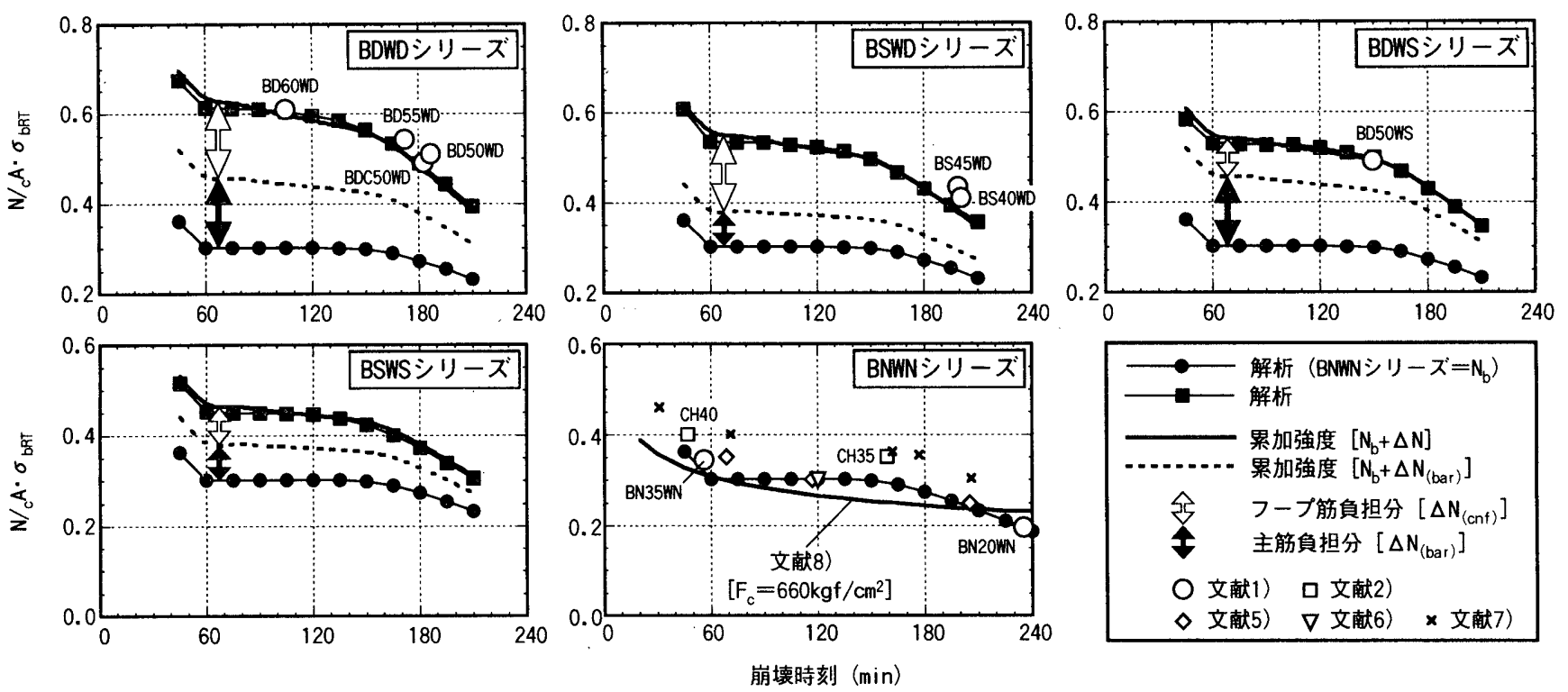

図17 解析解と簡略解との対応

試験体のほほ中央部に斜めひび割れが形成され、最終的な破壊状況 から判断する限り材端の曲げ圧縮破壊とは考え難い試験体も2 体 (BD50WS、BN20WN) 存在する。しかし、この最終破壊状況を、先 行した材端のモーメント劣化により部材全体の不安定現象が一瞬の うちに誘発された結果と捉えれば、実験で見られた上述二通りの破 壊形態は何れも、危険断面である柱頭・柱脚部が崩壊時刻を決定付 ける点に於いて、本解析手法が導く結果と一致していると云える。

柱長さ $L_{o}$ をパラメターとして $30 D$ までの解析を試みたが、柱長 さが10Dから $12 D$ 辺りで、曲率集中の発生する危険断面が柱頭・柱 脚要素から中央部に移動し、明らかに異なる破壊モード（いわゆる 長柱モード) に移行する。長柱に関する詳細な検討は別報に譲り、 ここでは、危険断面が柱頭・柱脚にある比較的短い柱に論を留める。

\section{2 累加強度法による鉄筋負担軸力の評価}

RCFT 柱に於ける鉄筋の補強効果を評価する手段として、累加強 度法を取り上げ、その妥当性ついて解析的に検証する。上述のよう に柱長さ $L_{o}$ が大凡 $10 D$ 以下であれば材端を危険断面と見なし得て、 かつ、柱頭は一定変位に拘束された状態であるから、座屈耐力を考 慮した長柱型の累加則は不要で短柱型の累加強度法を適用し得ると 考える。簡便の為、鋼管を無視し曲げモーメントの発生しない中心 圧縮状態を考え、鉄筋及びコンクリートは完全塑性材料と仮定寸る。 RCFT 柱とCFT 柱は、同時刻に崩壊しそのときの軸力を、それぞれ $N_{(R C F T)}, N_{(C F T)}$ とすると下式のように表記できる。

$$
\begin{aligned}
& N_{(R C F T)}={ }_{b} A \cdot{ }_{b} \sigma_{y T}+{ }_{c} A_{o} \cdot \sigma_{o u}+{ }_{c} A_{i}\left(\sigma_{i u}+k \cdot \sigma_{r}\right) \\
& N_{(C H T)}={ }_{c} A_{o} \cdot \sigma_{o u}+{ }_{c} A_{i} \cdot \sigma_{i u} \\
& \text { ここに、、 } A_{o}: \text { かぶりコンクリート断面積、 } A_{i}: コ ア コ \\
& \text { ンクリート断面積、 } \sigma_{o u}: \text { かぶりコンクリートの平均的 } \\
& \text { な崩壊時応力、 } \sigma_{i u} \text { : コアコンクリートの平均的な崩 } \\
& \text { 壊時応力、 }{ }_{b} A \text { : 主筋の全断面積、 }{ }_{b} \sigma_{y T} \text { : 主筋の崩壊時 } \\
& \text { 降伏強度、 } k \text { : コンファインドコンクリートの拘束係 } \\
& \text { 数 }(k=10.3) 、 \sigma_{r} \text { : コアコンクリートに作用する崩壊 } \\
& \text { 時刻の側圧で、(6)式による }
\end{aligned}
$$

$\mathrm{RCFT}$ 柱と CFT 柱との崩壊軸力の差 $\Delta N$ は、上記 2 式の差分であ るから直ちに(15)式を得る。その中で、 $\Delta N_{(b a r)}$ は主筋の軸力負担分 で、 $\Delta N_{(\mathrm{cnn})}$ はフープ筋による耐力上昇効果をコアコンクリートに作 用する側圧を介して、負担軸力として表現したものと云える。

$$
\begin{aligned}
\Delta N=N_{(R C F T)}-N_{(C F T)} & ={ }_{b} A \cdot{ }_{b} \sigma_{y T}+{ }_{c} A_{i} \cdot k \cdot \sigma_{r} \\
& =\Delta N_{(b a r)}+\Delta N_{(c n n)}
\end{aligned}
$$

次に、完全塑性材料を前提とする累加強度理論を劣化型の材料で あるコンクリートを含む部材に適用することの妥当性を検証しなく てはならない。図17は、簡略解(15)式にて抽出されるRCFT柱の鉄 筋による軸力增分を CFT 柱の精算解 $N_{b}$ (BNWNシリーズ）に足し 込んだ值とCDC解析によるRCFT柱の精算解とを比較したものであ る。CDC 解析に於ける柱長さ $L_{o}$ は、 $6 D$ である。図には、併せて文 献 1)及び文献 2)の実験值を表示した。累加強度法による簡略解は、 極僅かに危険側の予測を与える領域があるものの、どのシリーズも 偏りなく鉄筋補強による酎力増加傾向を捉えており、精算解及び実 験値と良好な対応を示していることが判る。

一方、基準とする BNWNシリーズに関しては、CDC解析による 精算解とともに文献 8)の評価式、及び既往の円形 CFT柱・複合載荷 加熱実験 $\left(R^{*}=0.02 \mathrm{rad}\right.$. $)$ の中ら常温のコンクリート強度 $\sigma_{b R T}$ が $586 \sim 696 \mathrm{kgf} / \mathrm{cm}^{2}$ の範囲にある結果 ${ }^{57.61 .7)}$ 全てを表示してみた。これ らの実験結果は、コンクリートの高温特性に加えて載荷形式 (文献 5)及び文献7)は、キャンチレバー型)、断面寸法 ( $\phi 250 \sim \phi 406.4) 、$ 柱長さ（柱全長換算で $6.9 D \sim 9.4 D ）$ が異なる為、精算解 $N_{b}$ との単 純な比較はできないが、精算解は実験值の傾向を上手く捉えるとと もに、その下限を包絡しており安全側の評価がなされている。

\section{5.まとめ}

複合載荷加熱を受けるRCFT柱及びCFT柱を対象として、高温下 の素材特性を反映させた $M-\phi$ 関係を導き、「系統的 CDC 数値積分 法」を適用して時刻歴挙動を追跡する手法を開発した。本解析手法 はRCFT柱及びCFT柱何れの場合も、筆者らが実施した実験結果と 極めて良好な対応を示し、RCFT柱及びCFT柱の熱弾塑性挙動を子 測・検証し得る有効な手段を確立したと考える。更に、これらビー ムコラムの崩壊プロセスについて考察を加え、柱長さが比較的短い ものでは、危険断面である柱頭・柱脚への曲率集中が全体崩壊の引 き金となっていることを示した。この崩壤メカニズムを踏まえた上 で、RCFT柱に於ける鉄筋の補強効果を簡便な累加強度式により定 
量評価し得ることを明らかにした。

勿論、本解析手法の有効性は、未だ限られた範囲で検証されたに すぎず、特に、コンクリート材料の高温特性の取り扱いや材端要素 長さの設定手法等に今後の検討課題を残す。

\section{付録 [系統的 CDC 数值積分法]}

\section{1. 従来型 CDC 樌分法}

付図1のような样の釣合い式は、下式で与えられる。

$$
M=M_{o}-Q \cdot x-N \cdot y
$$

荷重条件 $M_{o}$ と $Q$ が既知ならば、境界条件の一方、即ち初期条件を、 $y(0)=0$ 、 $y^{\prime}(0)=0$ として、柱頭から柱脚へ向かって数值棈分することによりたわみ曲線が 決定する。一般に次のような渐化式が利用される（f[]は $\boldsymbol{M}$ 一的関係を表す）。

$$
\begin{aligned}
& y_{i+1}=y_{i}+y_{i}^{\prime} \cdot d x+1 / 2 \cdot y_{i}^{\prime \prime} \cdot d x^{2} \\
& y_{i+1}^{\prime}=y_{i}^{\prime}+y_{i}^{\prime \prime} \cdot d x \\
& M_{i+1}=M_{O}-N \cdot y_{i+1}-Q \cdot d x \cdot i \\
& y_{i+1}^{\prime \prime}=f^{-1}\left[M_{i+1}\right]
\end{aligned}
$$

本論のように、材端の要素長さが比較的大きく、からキャンチレバー型への単 純化が不可能なビームコラム問题を解く場合に於いて、従来型 CDC 棈分法には 次に示すような咧路が存在する。

(A) (付 2)式の漸化式は、有限項に留めたTailor 展開の応用である。従って、曲 率は本来、区間 $d x$ の間の平均的な値となるべきであるが、この濑化式では $d x$ の端点に於ける曲㸉を取っているので、離散化の肌理が粗いとき、積分 䊅果に誤差が発生する。

(B) ビームコラムの問題は境界值問題であり、初期值と闹時に㮏䫓固定の条件、 $y^{\prime}(L)=0$ (Lは柱長さ) を満たさねばならない。これは付2)式による一方



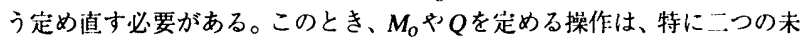
知数を京時に決定する必要がある変位制御問題に於いて、無原缇的な try and error法に頼らざるを得ない。

\section{2. 改良型 CDC 積分法}

上記 (A) で概括した積分誤差を解決する手段として、線形増分解析を取り げる。こ机は、支配方程式を（付 1）式の增分型とする。即ち、

$$
\Delta M=D_{t} \cdot \Delta y^{\prime \prime}=\Delta M_{0}-\Delta Q \cdot x-N \cdot \Delta y
$$

$D_{t}$ は $M-\phi$ 曲線.Eで、区間 $d x$ の中央位埧の曲率、即ち $y^{\prime \prime}(x+d x / 2)$ に対応す る接線俰数である。增分解は鸮めて小さく、たわみが $\Delta y$ だけ変化する間に $D_{l}$ は変化しないとすれいは、区間 $\mathrm{dx}$ の中央位置に於ける釣合いは(付3)式より、

$$
\begin{aligned}
D_{t} \cdot \Delta y^{\prime \prime} & =\Delta M_{o}-\Delta Q(x+d x / 2) \\
& \left.-N \mid \Delta y+\Delta y^{\prime} d x / 2+0.5 \Delta y^{\prime \prime}(d x / 2)^{2}\right\}
\end{aligned}
$$

従って、潄化式は(付 5)式のように得ら扎る $\left(g[]\right.$ は $D_{t}-\phi$ 関係老、 $y^{\prime \prime}{ }_{i}(t-1)$ は前時刻、或いは前ステップで確定した曲率を表す)。従来法とは異なり、本解 法では曲率 $y^{\prime \prime を 与 え る と モ ー メ ン ト ~} M$ (或いは $\left.D_{t}\right)$ が一意に定まるプロセスを 採っており、これは、付図2のように耐力少化域の収束解探索過程に於いて威力 を発揮する。なお、本論の解析では、四10に示すように愔影・柱脚荘素のみ $M$ 及び y"の評佃点を中点からフェイス位置に移動させている。

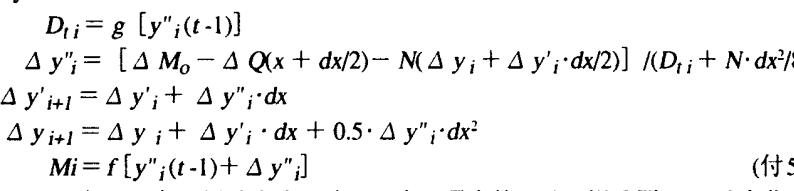

しかし、どのように增分を小さくしても、現実的には、増分間で $D_{l}$ は変化す る可能性があり、このとき增分解は誤差を持ちこれを奖加して到達解を求める と、制御不能な不釣合い誤差が新積する可能性がある。これが上の解法の久点で あり、次の 3 ，項でこれを解決する。

\section{3. 系統的な収束解探索手法}

上記（B）で指摘した問題点及び改良型 CDC 積分法の課題は次のように克服 できる。先ず、不釣り合いが解消していない系に、更に微小外力增分 $\Delta M_{0} \Delta$ $Q$ が作用したときの系の釗合い式は、

$$
M+\Delta M=M_{o}-Q \cdot x+\Delta M_{o}-\Delta Q \cdot x-N \cdot y-N \cdot \Delta y
$$

$$
\Delta M=D_{i} \cdot \Delta y^{\prime \prime} \text { とおいて、これを整理すると、 }
$$

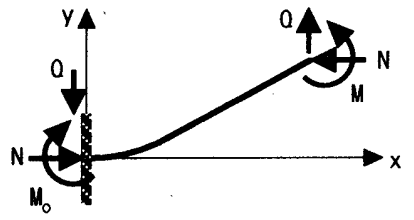

付図 1 解析モデル

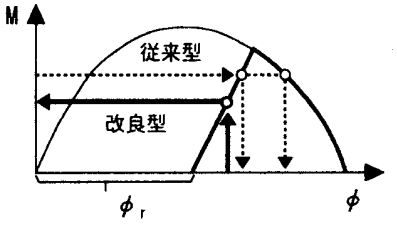

付図2 $M-\phi$ 関係道入の手順
$D_{i} \cdot \Delta y^{\prime \prime}+N \cdot \Delta y=M_{e r r}+\Delta M_{o}-\Delta Q \cdot x$

ここに、 $M_{\mathrm{err}}=M_{o}-Q \cdot x-M-N \cdot y$

(付 7)式を Newton法に於ける漸化式と見なし、不釣合い量 $M_{\mathrm{er}}$ を $\Delta y 、 \Delta M_{o}$ $\Delta Q$ により解消し、部材至るところの $M_{\mathrm{er}}$ が事実上ゼロになるまで繰り返す。

Newton 法の仮定により、漸近解析の各段に於いて(付 7)式中の $D_{l}$ は $d x$ 各区間 で一㸺である。従って、方程式(付 7)は線形で、こ机に着目すると解は次の乎䐈 で求め得る。付図の系について、次式を満たす解をそ机ぞれ順番に、 $\Delta y_{1} 、 \Delta$ $y_{2} 、 \Delta y_{3}$ とする。こ机らを、何れも個別に柱脚の境界条件を渵たす初期値問題 の解であるように解くと、(付 5)式の漸化式により求めるものが得られる。
(a) $D_{t} \cdot \Delta y^{\prime \prime}+N \cdot \Delta y=M_{e r}$
(b) $D_{1} \cdot \Delta y^{\prime \prime}+N \cdot \Delta y=1$
(c) $D_{t} \cdot \Delta y^{\prime \prime}+N \cdot \Delta y=x$

そうすると、方程式(付 7)の解は、重ねあわせの原理により、 $\Delta y(x)=\Delta y_{l}(x)+\Delta M_{0} \cdot \Delta y_{2}(x)-\Delta Q \cdot \Delta y_{3}(x)$

この解は、石端（柱頭）の境界条件、即ち次式を満たす必要がある。 $\Delta y(L)=\Delta \delta_{h}=\Delta y_{l}(L)+\Delta M_{0} \cdot \Delta y_{2}(L)-\Delta Q \cdot \Delta y_{3}(L)$ これより、

$\Delta y^{\prime}(L)=0=\Delta y_{l}^{\prime}(L)+\Delta M_{0} \cdot \Delta y_{2}^{\prime}(L)-\Delta Q \cdot \Delta y_{3}^{\prime}(L)$

1) 荷重制御問題では、水平力增分 $\Delta Q$ を与えて方程式(付 9$)$ を $\Delta \delta_{h}$ と $\Delta M_{O}$ について解く。

2 ) 変位制御問題では、水平変位増分 $\Delta \delta_{h}$ をえて方程式(付 9)を $\Delta M_{o}$ と $\triangle Q$ について解

上に見たように、Newton法の漸近解析の染組みと、線形化方程式を解くと云 う二段の操作を導入することにより、CDC法にはつきものの場当たり的、無原 則的な収束解の探索手段を講ずることなく、荷重制御問題及び変位制御問題何孔 にも対応可能な系統的な収束解探索手順を構築することが可能となる。

\section{[参考文献]}

1）上田弘樹、一戸康生、小野徹郎、久保田一男、湯谷孝夫、飯田仲男：鉄筋で 補強した酎火被覆のないCFT柱の酎火性能に関する研究、その1～その2、日 本建築学会大会学術講演梗概集（九州）、No3013-3014、pp25-28、1998.9

2 ）湯谷孝夫、松谷輝雄、小野徹郎、中島将好、上田弘樹、中里卓三、....万康生: 的火被覆の無い充填型鋼管コンクリート柱の耐火性能に関する研究、その1 その 4、日本建築学会大会学術講演梗概集 (近畿)、No3019-3022、pp37-44、1996.9

3) 久保田一男、一戸康生、飯田仲男、小野徹郎、内海善彦、湯谷孝夫：フープ 筋で拘束されたコンファインドコンクリートの高温特性、その1一その2、日 本建築学会大会学術講演梗概集（中国）、No3035-3036、pp75-78、1999.9

4) 斎藤光、上杉英樹：角形鋼管コンクリート柱の耐火試験、日本建築学会大会 学術講演梗概集 (中国)、No3012、pp2107-2108、1977.10

5 ）東間敬造、吉野茂、今村輝武、畑户龍夫：無酎火被覆鋼管コンクリート柱の 酎火性能一複合載荷加熱実験一、日本建築学会大会学術講演梗概集 (関東)、 No3084、pp189-190、1997.9

6 ）宮本圭一、大内富夫、福本敏之、桜本文敏、䦥田徹志：高強度材料を用いた コンクリート充填鋼管柱の載荷加熱実験、日本建築学会大会学術講演梗概集 (中国)、No3025、pp55-56、1998.9

7）酒井雅康、池田憲一、、村上行夫、菊田繁差：高強度材料を用いた無酎火被㺕 CFT 柱の酎火性能（その3．酎火性能及び観察結果）、日本建築学会大会学術 講演梗概集（九州）、No3009、ppl7-18、1998.9

8）社㳡法人・新都市ハウジング協会：CFT 構造技術指針・闰解説、2000.8

9) 夙部猛、作本好文、岡田忠義、山口種美：FR鋼を使用した鋼管コンクリート 柱の酎火試験時挙動の数偭解析、構造工学論文集 Vol.40B、pp605-614、1994.3

10）古村福次郎、安部武雄、岡部猛、金和中：火災温度域を考慮した鋼材の単軸応 力ーひずみ関係式とその鋼構造骨組熱変形解析への適用、日本建箘学会構造系 論文集、第 363 号、ppl10-117、1986.5

11) Eurocode $4:$ Design of Composite Steel and Concrete Structures

12) Richart, F.E., Brandzaeg, A. and Brown, R. L.: A Study on the Failure of Concrete under Compressive Stresses, University of Illinois Engineering Experimental Station, Bulletin No.185, 1928

13) Fujimoto, M., Funumura, F. and Abe, T. : Primary Creep of Structural Steel(SM50A) at High Temperatures, Trans. of AL, No.306, pp92-100, 1981.8

14）金和中、古村福次郎、唄舅熙、安部武雄：高温時における普通強度コンクリー トの初期クリープ性状に関する研究、日本建築学会大会学術講演梗概集（近 畿)、No3004、pp759-760、1982.10

15) Fujimoto, M., Furumura, F. and Abe, T.:Effect of Step-wise Change of Stress on Primary Creep of Structural Steel, Trans. of AIJ, No.308, pp165-174, 1981.10

16) Anderberg, Y. and Thelandersson, S. : Stress and Deformation Characteristics of Concrete at high Temperature, 2. Experimental Investigation and Material Behavior Model, Bulletin of Lund Institute of Technology, No.54, Sweden, 1976

17）上杉英樹、関美和、丹波博則、斎藤光：火災時におけるコンクリート充填鋼管 柱の荷重支持能力に関する解析的研究、構造工学論文集 Vol.42B、pp379-386、 1996.3

18）深昌英邦、箖野揵輔、川口涪：不安定な応力一ひずみ関係を持つ柱材の弾塑性 変形解析に関寸る研究、日本建築学会大会学術講演梗概集 (東海)、No21619、 ppl171-1172、1994.9

19）日本建築学会：鋼構造座屈設計指針、7.5.3トラス架構の安定性とトラス梁の 変形能力、1996.1

20）日本建築学会：コンクリート充填鋼管構造設計施工指針、3.5.1 復元力特性王 デル、1997.10 